\title{
Quality of Vermicompost and Microbial Community Diversity Affected by the Contrasting Temperature during Vermicomposting of Dewatered Sludge
}

\author{
Hongwei Zhang ${ }^{(}$, Jianhui Li, Yingying Zhang and Kui Huang *(D) \\ School of Environmental and Municipal Engineering, Lanzhou Jiaotong University, Lanzhou 730070, China; \\ zhw@mail.lzjtu.cn (H.Z.); 0618086@stu.mail.lzjtu.cn (J.L.); 0618116@stu.mail.lzjtu.cn (Y.Z.) \\ * Correspondence: huangkui@mail.lzjtu.cn
}

Received: 4 February 2020; Accepted: 3 March 2020; Published: 7 March 2020

\begin{abstract}
This study aimed to investigate the effects of temperature on the quality of vermicompost and microbial profiles of dewatered sludge during vermicomposting. To do this, fresh sludge was separately vermicomposted with the earthworm Eisenia fetida under different temperature regimes, specifically, $15^{\circ} \mathrm{C}, 20^{\circ} \mathrm{C}$, and $25^{\circ} \mathrm{C}$. The results showed that the growth rate of earthworms increased with temperature. Moreover, the lowest organic matter content along with the highest electrical conductivity, ammonia, and nitrate content in sludge were recorded for $25^{\circ} \mathrm{C}$ indicating that increasing temperature significantly accelerated decomposition, mineralization, and nitrification. In addition, higher temperature significantly enhanced microbial activity in the first 30 days of vermicomposting, also exhibiting the fastest stabilization at $25^{\circ} \mathrm{C}$. High throughput sequencing results further revealed that the alpha diversity of the bacterial community was enhanced with increasing temperature resulting in distinct bacterial genera in each vermicompost. This study suggests that quality of vermicompost and dominant bacterial community are strongly influenced by the contrasting temperature during vermicomposting of sludge, with the optimal performance at $25^{\circ} \mathrm{C}$.
\end{abstract}

Keywords: earthworms; microorganisms; sludge recycling; temperature; vermicomposting

\section{Introduction}

With the development of China in recent years, the government has also built thousands of wastewater treatment plants, generating large amounts of dewatered sludge with several pollutants that are difficult to be treated [1,2]. Accordingly, the total amount of dewatered sludge in China is expected to exceed 50 million tons ( $80 \%$ water content) in 2020 [3]. Compared with incineration and landfills, the sludge fertilizer product combined with the agricultural use is deemed as a potential method of recycling to resolve the sludge problem in China [1] based on the control standards for sludge products for agricultural use (GB 4284-2018). Vermicomposting is a biochemical method for converting sludge into high-value organic microbial fertilizer by the joint action of earthworms and microorganisms [4-7]. As a green technology, plenty of vermicomposting factories for treating sludge have been recently established in China allowing them to profit highly from vermicompost and vermiculture in the process.

In a vermicomposting system, both earthworms and microorganisms play important roles in the decomposition and conversion of sludge [8]. Relative to microbes, earthworms make a larger contribution to sludge stabilization through gut digestion, mucus production, and then casting. This makes earthworms significant in vermicomposting. Accordingly, many environmental factors, such as temperature, moisture, noise, and light, may also influence the growth of earthworms, and thus, also modify properties of the final products $[4,5]$. Among these variables, temperature is considered 
one of the most critical factors affecting the growth and reproduction of earthworms $[9,10]$. For instance, Eisenia fetida as a ubiquitous epigenetic species capable of vermicomposting exhibited wide tolerance to a broad temperature range $\left(15-25^{\circ} \mathrm{C}\right)$ for their growth [11]. Previous studies also indicate high variability in the temperature used for vermicomposting with most using room temperature, also suggesting a wide range of temperature useful for treating sludge $[6,12,13]$. Only a few publications clearly reported that $20{ }^{\circ} \mathrm{C}$ was the optimal temperature condition for treating activated sludge [14]. Given that the growth of earthworms is strongly associated with temperature, different regimes may also affect the quality of the vermicomposting product and its agricultural value. Hence, understanding the optimal temperature condition to operate vermicomposting of sludge is vital to drive the development of the vermicomposting industry.

Although the use of earthworms is popular in vermicomposting systems, microorganisms also play important roles in decomposing and converting the organic matter present in sludge $[8,15]$. In addition, the dewatered sludge is mainly characterized by active microbes and debris from dead cells and particulate matter [1]. Consequently, the activity, abundance, and community composition of microbes in sludge may be strongly associated with the vermicomposting efficiency and sludge quality $[8,13]$. For other sludge biodegradation systems, the impact of temperature on microbial profiles has been well-investigated, such as on anaerobic digestion [16,17], composting [18,19], and vermifiltration [20]. Even in soil systems, temperature also showed an intensive effect on microbial growth, activity, and community structuring within a short period, and thus affects decomposition of organic substances [21-23]. However, until now, the effect of temperature on microbial activity, abundance, and community composition during vermicomposting of sludge remains unclear, while it is strongly associated with the quality of vermicompost.

The objectives of this study then were to investigate the effect of temperature on vermicomposting quality for treating sludge, and to understand the effect of temperature on microbial activity, abundance, and community structuring during vermicomposting. Taking into account that the optimal temperature for the growth of Eisenia fetida was from 15 to $25^{\circ} \mathrm{C}$, three vermicomposting treatments for recycling sludge at $15^{\circ} \mathrm{C}, 20^{\circ} \mathrm{C}$, and $25^{\circ} \mathrm{C}$ were compared in this study.

\section{Materials and Methods}

\subsection{Experimental Setup}

The earthworm Eisenia fetida, which had been cultured by dewatered sludge for 2 years in the laboratory, was selected for the vermicomposting experiment. The dewatered sludge was obtained from Lanzhou Qilihe wastewater treatment plant, Anning District, Lanzhou, China. Based on the previously used method [12], the dewatered sludge was pelleted into small particles of $5 \mathrm{~mm}$ size to enhance oxygenation of the sludge. The main properties of the sludge used are summarized in Table 1.

Table 1. Physicochemical properties of the initial sludge and final vermicomposting products at $15{ }^{\circ} \mathrm{C}$, $20^{\circ} \mathrm{C}$, and $25^{\circ} \mathrm{C}$. Value are means $\pm \operatorname{SE}(n=3)$.

\begin{tabular}{|c|c|c|c|c|}
\hline \multirow{2}{*}{ Parameters } & \multirow{2}{*}{$\begin{array}{l}\text { Initial } \\
\text { Sludge }\end{array}$} & \multicolumn{3}{|c|}{ Vermicomposting after 60 days } \\
\hline & & $15^{\circ} \mathrm{C}$ & $20^{\circ} \mathrm{C}$ & $25^{\circ} \mathrm{C}$ \\
\hline Water content $(\%)$ & $80.38 \pm 0.01$ & $80.15 \pm 0.0$ & $80.37 \pm 0.0$ & $80.53 \pm 0.0$ \\
\hline Organic matter (\%) & $68.0 \pm 7.7$ & $55.0 \pm 1.16$ & $51.7 \pm 1.99$ & $49.8 \pm 1.42$ \\
\hline $\mathrm{pH}$ & $6.77 \pm 0.005$ & $6.53 \pm 0.005$ & $6.77 \pm 0.00$ & $7.01 \pm 0.00$ \\
\hline Electrical conductivity ( $\mu \mathrm{s} / \mathrm{cm})$ & $573 \pm 8.49$ & $911.5 \pm 2.04$ & $1097.5 \pm 6.94$ & $2100 \pm 16.33$ \\
\hline Dissolved organic carbon (mg/kg) & $16.69 \pm 0.13$ & $14.05 \pm 0.04$ & $13.92 \pm 0.04$ & $9.17 \pm 0.05$ \\
\hline Ammonium $(\mathrm{mg} / \mathrm{kg})$ & $7.36 \pm 0.08$ & $103.79 \pm 0.76$ & $206.06 \pm 0.23$ & $238.91 \pm 2.9$ \\
\hline Nitrate $(\mathrm{mg} / \mathrm{kg})$ & $10.26 \pm 2.0$ & $219.91 \pm 45.15$ & $285.10 \pm 9.10$ & $1389.49 \pm 47.07$ \\
\hline Ammonium/nitrate & $0.74 \pm 0.19$ & $0.24 \pm 0.04$ & $0.67 \pm 0.04$ & $0.13 \pm 0.05$ \\
\hline Microbial biomass carbon (g/kg) & $105.61 \pm 10.6$ & $15.63 \pm 0.98$ & $8.50 \pm 0.18$ & $6.71 \pm 1.08$ \\
\hline Dehydrogenase activity $(\mathrm{mg} / \mathrm{g} / \mathrm{h})$ & $28.06 \pm 1.34$ & $0.49 \pm 0.08$ & $0.49 \pm 0.02$ & $0.27 \pm 0.01$ \\
\hline
\end{tabular}


Since $15-25^{\circ} \mathrm{C}$ had been reported to be suitable for the growth of Eisenia fetida [24], three temperature regimes including 15,20 , and $25^{\circ} \mathrm{C}$ were separately established for the vermicomposting of sludge. Nine [11] metal pots with the size of $36 \mathrm{~cm} \times 12 \mathrm{~cm}$ (diameter $\times$ height) were used as vermireactors, with triplicate for each treatment. For each reactor, 100 young and active earthworms with an average weight of $0.5 \mathrm{~g}$ were inoculated into each vermireactor filled with $4 \mathrm{~kg}$ fresh sludge. This density of earthworms was based on the previous studies [6,12]. To maintain the moisture of $70-80 \%$, each reactor was covered with a plastic film with some small holes. Subsequently, three replicate reactors were placed into three incubators (Yiheng, Shanghai, China) with constant temperatures of $15^{\circ} \mathrm{C}$, $20^{\circ} \mathrm{C}$, and $25^{\circ} \mathrm{C}$, respectively. During the experiment, all reactors were turned over twice a week to homogenize the vermicompost. After 60 days, the experiments were stopped, and the earthworms and their cocoons were weighed and counted separately. The samples were collected at the interval of 10 days, and subsequently stored in $4{ }^{\circ} \mathrm{C}$ and $-20^{\circ} \mathrm{C}$ for further use.

\subsection{Physicochemical and Enzymatic Properties}

The water and organic matter content were determined by drying the samples in the oven for $12 \mathrm{~h}$ at $105{ }^{\circ} \mathrm{C}$ and for $6 \mathrm{~h}$ at $550^{\circ} \mathrm{C}$, respectively. The mixture of dry sample and distilled water $(1: 50, \mathrm{w} / \mathrm{v})$ was used to measure the $\mathrm{pH}$ and electrical conductivity using a pHS-3C acidometer and a conductivity meter, respectively. The same water mixture was used to determine the ammonia-nitrogen $\left(\mathrm{NH}_{4}{ }^{+}\right)$, nitrate-nitrogen $\left(\mathrm{NO}_{3}{ }^{-}\right)$, and available phosphate $\left(\mathrm{PO}_{4}{ }^{3-}\right)$ with the spectrophotometric methods. The fresh sludge was fumigated with chloroform before being used to measure the microbial biomass carbon (MBC) via the spectrophotometric method following Fu et al. [12]. Dehydrogenase activity (DHA) was also determined to evaluate microbial activity using the triphenyl tetrazolium chloride (TTC) method [6].

\subsection{DNA Extraction, PCR and Sequencing}

The commercially available Power Soil ${ }^{\circledR}$ DNA Isolation Kit (MO BIO, Carlsbad, CA, USA) was used for DNA extraction without modification. Before being stored at $-40{ }^{\circ} \mathrm{C}$, the extracted DNA was diluted 20-fold using DNA-free water to decrease the pollutants.

V3-V4 regions of the bacterial 16S rRNA gene were amplified using the universal primers of 304f-806r [6]. The Polymerase chain reaction (PCR) was carried out in a $25 \mu 1$ mixture comprised of $1 \mu \mathrm{L}$ DNA template, $2.5 \mu \mathrm{L}$ of each forward and reverse primer $(0.5 \mu \mathrm{M}$ each), $25 \mu \mathrm{L}$ polymerase (Phusion ${ }^{\circledR}$ High-Fidelity PCR Master Mix, New England Biolabs, Beijing, China), and $19 \mu \mathrm{L}$ DNA-free water. The amplification conditions with 30 cycles included denaturation at $94{ }^{\circ} \mathrm{C}$ for $30 \mathrm{~s}$, annealing at $58{ }^{\circ} \mathrm{C}$ for $1 \mathrm{~min}$, and extension at $72{ }^{\circ} \mathrm{C}$ for $1 \mathrm{~min}$. After checking by electrophoresis with $2 \%$ agarose gel, the PCR products were recovered and then purified with a GeneJET Gel Extraction Kit (Thermo Scientific, Shanghai, China). The sequence library was built with an Ion Plus Fragment Library Kit 48 rxns (Thermo Fisher, Shanghai, China) and then quality checked with a Qubit ${ }^{\circledR} 2.0$ Fluorometer (Thermo Scientific, Shanghai, China). The sequencing was performed on a Life Ion $\mathrm{S} 5^{\mathrm{TM}}$ platform at Novogene Bioinformatics Technology Co., Ltd. (Beijing, China). After removing the low-quality parts of the sequences with the Cutadapt software (V1.9.1, Stockholm, Sweden), the reads were compared with the UCHIME algorithm (V11, Tiburon, CA, USA) and the Gold database of genomes (V7, Los Angeles, CA, USA). Quality reads were then clustered to generate operational taxonomic units (OTUs) at the 97\% similarity level using the UPARSE package (V7.0.1001, Los Angeles, CA, USA). A representative sequence of each OTU was assigned taxonomy in the Ribosomal Database Project (RDP) classifier (V11, East Lansing, MI, USA) [6].

\subsection{Statistical Methods}

One-way ANOVA was used to evaluate differences between treatments with a significant level at $p<0.05$ using the SPSS 17.0 software. Such parameters as organic matter (OM), dissolved organic carbon (DOC), electrical conductivity (EC), $\mathrm{NH}_{4}{ }^{+} / \mathrm{NO}_{3}{ }^{-}$, microbial biomass carbon (MBC), and dehydrogenase activity (DHA) were used to evaluate significant correlated factors affecting stabilization 
of vermicomposting under three temperature conditions, which were plotted using principal component analysis (PCA) implemented in the Statistica 10.0 software (Statsoft Inc. Tulsa, USA). A heatmap diagram of the dominant bacterial community was drawn using the Heml 1.0 software (Wuhan, China). The Venn diagram showing the extent of overlap in bacterial OTUs (at the $3 \%$ evolutionary distance) among the different treatments was done in the Origin 8.0 software (OriginLab, Northampton, MA, USA).

\section{Results}

\subsection{Changes in Physicochemical Properties}

After the experiment, the observed growth rates of earthworms at $15{ }^{\circ} \mathrm{C}, 20^{\circ} \mathrm{C}$, and $25^{\circ} \mathrm{C}$ were $0.43,0.82$, and $1.17 \mathrm{mg} /$ worms/day, respectively. Those at $25^{\circ} \mathrm{C}$ showed $90.7 \%$ and $172 \%$ higher growth rates than at $20^{\circ} \mathrm{C}$ and $15^{\circ} \mathrm{C}$, respectively. These results clearly indicate that higher temperature also stimulated increased growth rates of earthworms consistent with previous observations $[25,26]$. However, Hait and Tare [14] reported that $20^{\circ} \mathrm{C}$ was the optimal temperature condition for treating activated sludge, which could be due to the differences in the substrate used in vermicomposting.

During vermicomposting, $\mathrm{pH}$ values showed little fluctuation, which ranged from 6.5 to 7.1 in the three treatments. Towards the end of the incubation, no significant difference in $\mathrm{pH}$ was observed, indicating that the effect of temperature on the $\mathrm{pH}$ value was insignificant. In contrast, electrical conductivity displayed a gradual increment towards the end of the experiment (Figure 1a). The increasing electrical conductivity could be due to the remineralization of organic substances in dewatered sludge [14]. For the final vermicomposting product, the electrical conductivity at $25^{\circ} \mathrm{C}$ was significantly higher than at $20^{\circ} \mathrm{C}$ and $15^{\circ} \mathrm{C}$ (1.91 and 2.30 times, respectively). Such findings suggest that higher temperature could strongly accelerate remineralization in sludge during vermicomposting.

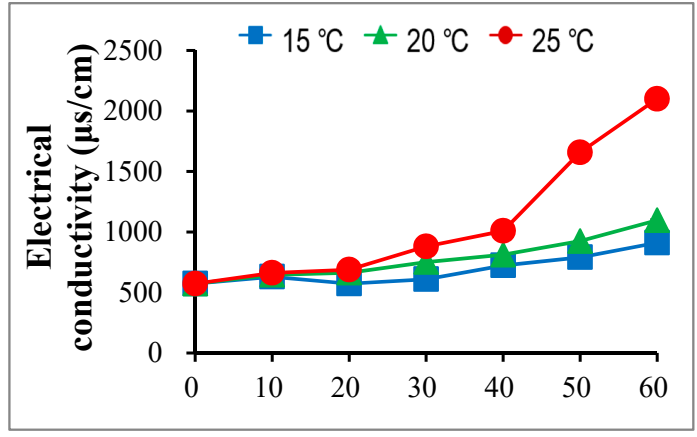

(a)

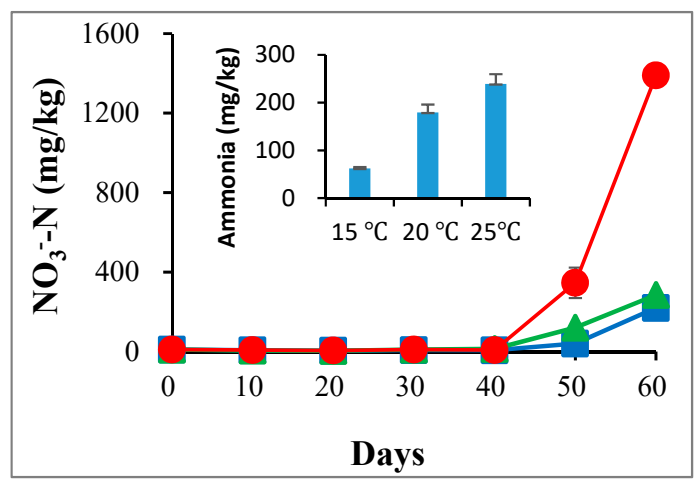

(c)

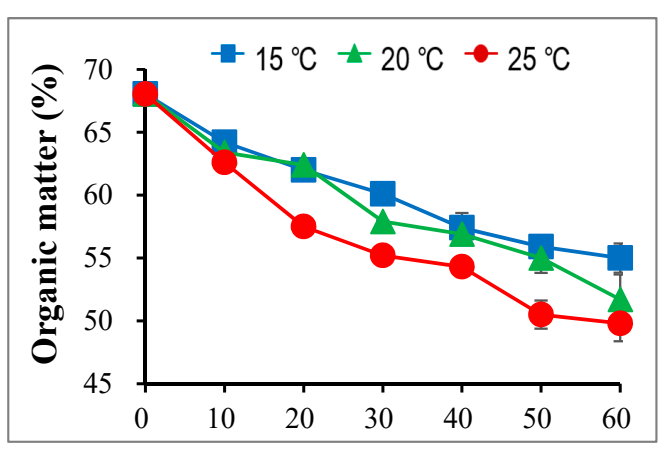

(b)

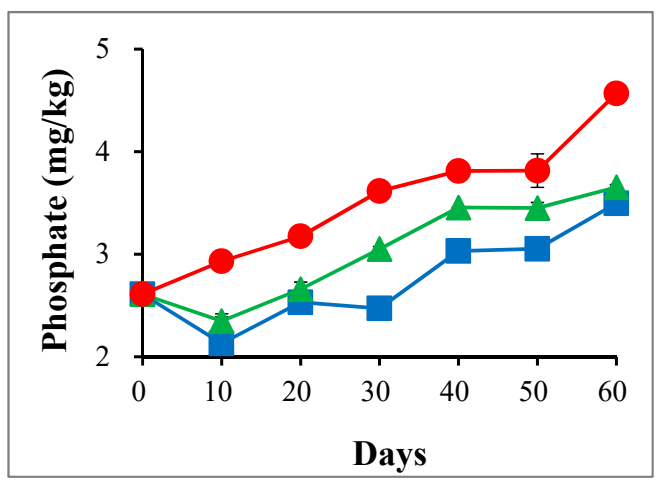

(d)

Figure 1. Changes of electrical conductivity (a), organic matter (b), ammonium, nitrate (c), and phosphate (d) levels during vermicomposting of sludge at $15{ }^{\circ} \mathrm{C}, 20^{\circ} \mathrm{C}$, and $25^{\circ} \mathrm{C}$, respectively. 
As shown in Figure 1b, the organic matter in all treatments markedly decreased during vermicomposting, showing the largest drop at $25^{\circ} \mathrm{C}$. In the end, the OM dropped by $19.1 \%, 25 \%$, and $26.7 \%$ in the reactors at $15{ }^{\circ} \mathrm{C}, 20^{\circ} \mathrm{C}$, and $25^{\circ} \mathrm{C}$, respectively. This shows that conditions with higher temperature also had a higher decomposition rate of organic matter in the sludge. Similarly, the highest removal rate of volatile suspended solids was found in the seasons with higher temperature in the vermifilters for treating excess sludge [20]. However, Garg and Gupta [26] argued that OM degradation rate of household waste was higher in winter than that in the summer season in India during the vermicomposting process. Combined with the earlier finding of the earthworms' growth rate in this study, it may be deduced that higher temperature could have first stimulated the earthworms' activity before promoting the decomposition of OM.

Dewatered sludge is mainly comprised of microorganisms and their metabolic products, where proteins tend to have a larger share than other compounds, such as saccharides, lipids, and nucleic acid [1]. Therefore, degradation and transformation of nitrogenous substances were closely associated with stabilization of the sludge. Generally, $\mathrm{NH}_{4}{ }^{+}$and $\mathrm{NO}_{3}{ }^{-}$are considered important indices for assessing the vermicomposting stabilization process $[27,28]$. As shown in Figure $1 c$, the highest ammonification rate was recorded in the $25^{\circ} \mathrm{C}$ reactor, significantly higher than for the other two treatments. Accordingly, the dewatered sludge is mainly comprised of proteins, microorganisms, and some organic substances [13]. The higher ammonification rate in the $25^{\circ} \mathrm{C}$ reactor may be linked with the organic matter decomposition, especially of protein-like substances. Meanwhile, the $\mathrm{NO}_{3}{ }^{-}$ content in all treatments was close to zero until after 40 days, which was followed by a drastic increase towards the end of the experiment (Figure 1c). The sharp increase in the nitrate level from the mid-phase of vermicomposting is consistent with previous reports [6,12]. Finally, the largest increase was observed at $25^{\circ} \mathrm{C}$, followed by the treatments of $20^{\circ} \mathrm{C}$ and $15^{\circ} \mathrm{C}$, indicating that higher temperature can also induce nitrification. This could be because ammonia-oxidizing microorganisms are more active at $25^{\circ} \mathrm{C}$ than at $15^{\circ} \mathrm{C}$ and $20^{\circ} \mathrm{C}$ [29]. Gubry-Rangin et al. [30] also reported that the optimum temperature for nitrification is $20^{\circ} \mathrm{C}$ to $30^{\circ} \mathrm{C}$, depending on the $\mathrm{pH}$ value of the surrounding environment.

In addition, orthophosphate levels exhibited a continuous enhancement in all treatments for the duration of the entire experiment as illustrated in Figure 1d. Like other inorganic salts, the highest orthophosphate level was also observed at $25^{\circ} \mathrm{C}$. Generally, accumulation of orthophosphates in the sludge vermicompost may probably be related to sludge remineralization facilitated by earthworms, corroborating previous reports $[6,12]$. As a result, the highest electrical conductivity observed at $25^{\circ} \mathrm{C}$ was consistent with the highest concentration of orthophosphates observed in the present study.

\subsection{Changes in Microbial Activity and Abundance}

The results showed (Figure 2) that both microbial activity and biomass in the sludge showed rapid reduction in all treatments during the incubation, which was also observed in previous studies of vermicomposting for dewatered sludge [12,13].

Such findings may be due to the rapid loss of high OM and MBC in the initial sludge. For the DHA, the higher activity was observed at $25^{\circ} \mathrm{C}$ during the first 30 days, which was earlier compared to the other two treatments. These findings suggest that temperature can enrich microbial activity during the first phase of vermicomposting, which may also imply that sludge decomposition mainly occurred in the first 30 days. As a result, no significant difference in the DHA was observed among the three treatments after 30 days, which may be ascribed to the loss of available OM for microbial growth. The temperature fluctuation positively correlated with microbial activity, which has also been detected in several biosolid treatment systems $[17,18,20]$. 


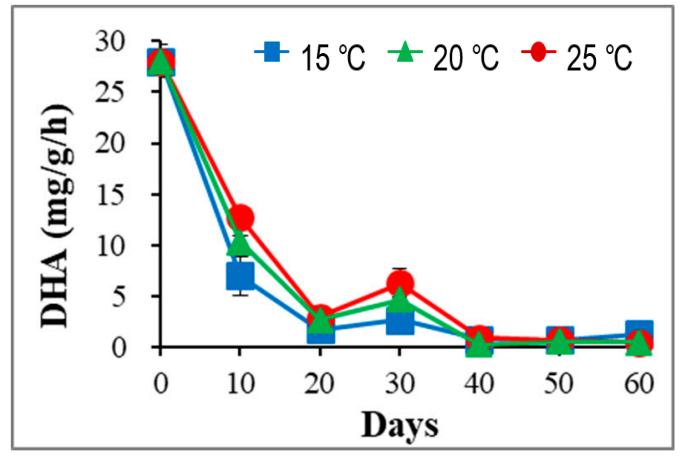

(a)

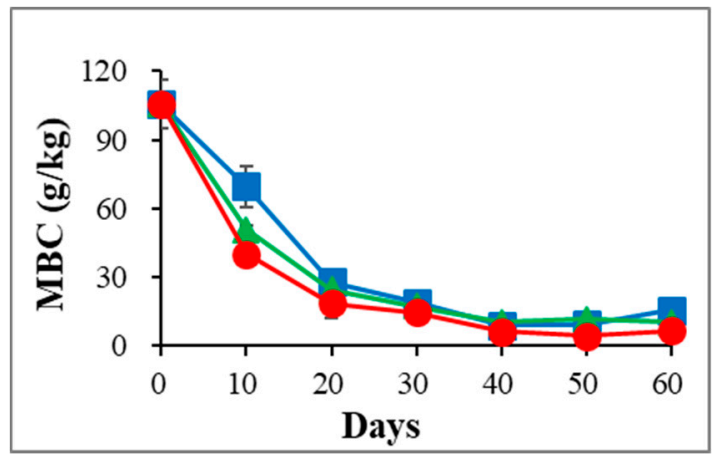

(b)

Figure 2. (a) Changes of dehydrogenase activity (DHA) and (b) microbial biomass carbon (MBC), during vermicomposting of sludge at $15^{\circ} \mathrm{C}, 20^{\circ} \mathrm{C}$, and $25^{\circ} \mathrm{C}$, respectively.

As for the MBC, temperature showed negative effects on microbial biomass (Figure 2), opposite to what has been reported by other studies [23,31]. Apparently, it seems that higher temperature decreased the abundance of the active microbial population during the vermicomposting of sludge. In fact, the MBC was strongly linked with the OM concentration, which is an intermediate product of decomposition that can be rapidly transformed and decomposed by microbial activity [23]. Hence, the larger loss of the $\mathrm{MBC}$ at $25{ }^{\circ} \mathrm{C}$ could probably be due to faster transformation and decomposition of $\mathrm{OM}$ during vermicomposting. Moreover, higher temperature may directly enhance the activity of earthworms, boosting the predatory effects of earthworms on the microbial population. In addition, a related study documented that temperature had only minor effects on both bacterial and fungal growth below $30^{\circ} \mathrm{C}$ [32].

\subsection{Stabilization Process. of Vermicomposting}

As depicted in Figure 3, the cumulative variance of $80.9 \%$ and high loading rate of all parameters (more than 0.75) in the first and the second principal components indicate that the selected parameters were reasonable to be used in assessing the stabilization process in the present study. Specifically, OM, $\mathrm{DOC}, \mathrm{MBC}$, and DHA were significantly positively correlated with the first principal component, which indicates capability for decomposition and remineralization of sludge. In addition, $\mathrm{NH}_{4}{ }^{+} / \mathrm{NO}_{3}{ }^{-}$had a significant positive correlation $\left(r^{2}=0.92\right)$ with the second principal component, possibly reflecting ammonification and ammonia oxidation processes.

Based on Figure 3, the vermicomposting process could be divided into three stages: days 0-10, days $10-40$, and days 50-60. Specifically, in the first stage, the temperature began to affect the decomposition, since the projective position to the $25{ }^{\circ} \mathrm{C}$ treatment significantly differed with the other two treatments in the fourth quadrant. In the second stage, all points were distributed in the first and the second quadrants with a positive relationship with $\mathrm{NH}_{4}{ }^{+} / \mathrm{NO}_{3}{ }^{-}$suggesting that intense ammonification occurred during this stage, especially in the $25{ }^{\circ} \mathrm{C}$ reactor on day 40 . In the last stage, all treatments positioned in the third quadrant also positively correlated with $\mathrm{EC}$, but negatively with $\mathrm{OM}, \mathrm{DOC}, \mathrm{MBC}, \mathrm{DHA}$, and $\mathrm{NH}_{4}{ }^{+} / \mathrm{NO}_{3}{ }^{-}$. During the entire process, the $25{ }^{\circ} \mathrm{C}$ treatment significantly differed with the other two treatments implying that the sludge could be rapidly stabilized at $25^{\circ} \mathrm{C}$. Consequently, it can be inferred that higher temperature could have positive effects on stabilization of vermicomposting. Further, it does mean that the sludge vermicompost obtained at $25^{\circ} \mathrm{C}$ is better as a soil fertilizer, as suggested by [15]. 


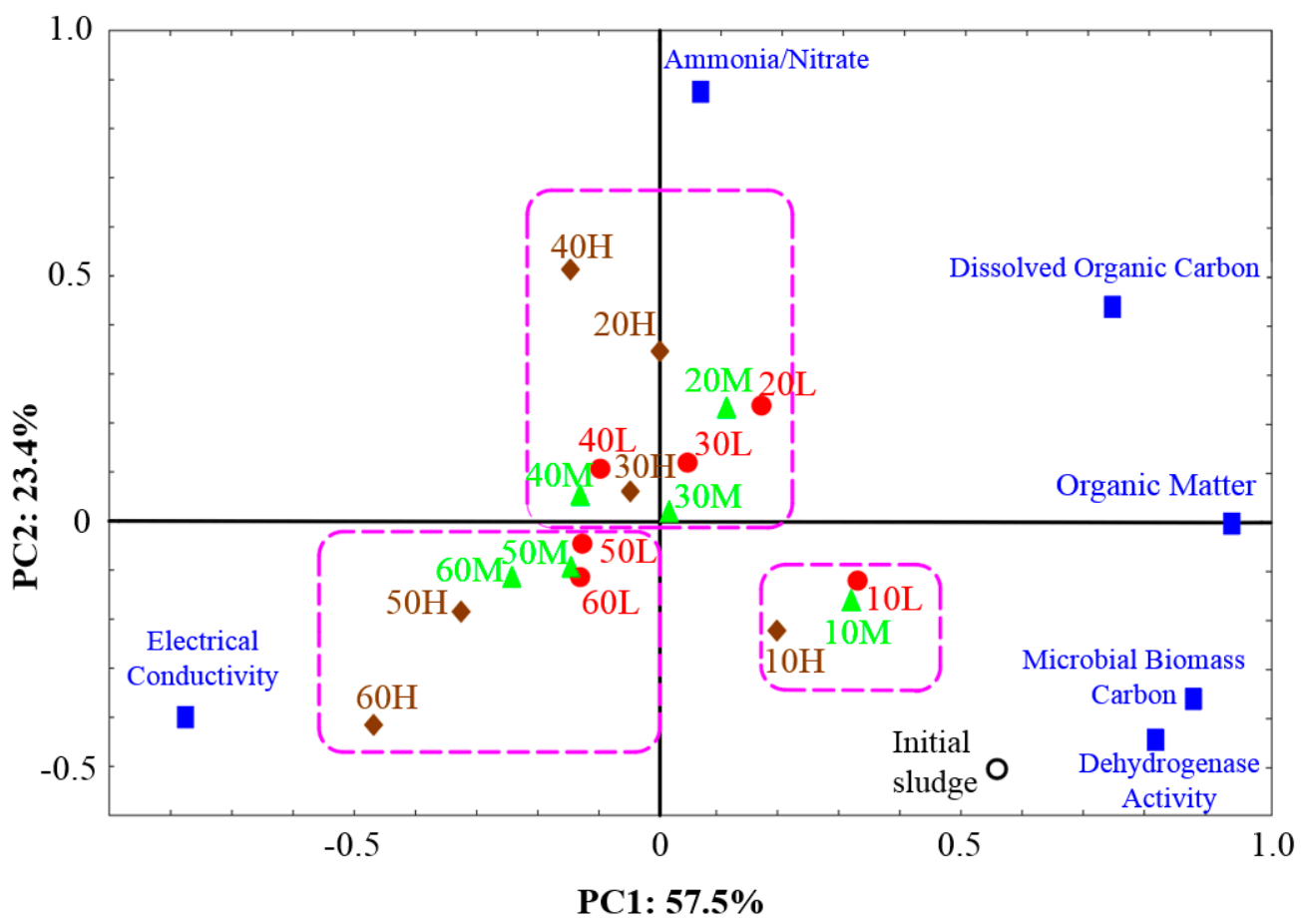

Figure 3. Principal component analysis of vermicomposting of sludge under three different temperature conditions. Letters " $\mathrm{L}$ ", “ $\mathrm{M}$ ", and " $\mathrm{H}$ " represent the temperatures of $15^{\circ} \mathrm{C}, 20^{\circ} \mathrm{C}$ and $25^{\circ} \mathrm{C}$, respectively. The numbers at the head of $\mathrm{L}, \mathrm{M}$, and $\mathrm{S}$ mean vermicomposting samples collected on day 10, 20, 30, 40,50 , and 60 . The blue diamond blocks mean the different parameters of stability. The green dotted cycles represent the different stages of vermicomposting.

\subsection{Changes in Microbial Community Structure}

After sequencing, a total of $61,873,65,436$, and 66,713 quality reads were generated from the $15^{\circ} \mathrm{C}$, $20^{\circ} \mathrm{C}$, and $25^{\circ} \mathrm{C}$ treatments, respectively. As shown in Table 2, the Shannon and Chao1 indices had the highest values at $25^{\circ} \mathrm{C}$, followed by the $15^{\circ} \mathrm{C}$ and $20^{\circ} \mathrm{C}$ treatments. These results indicate that both community diversity and richness were promoted by higher temperature during vermicomposting. This result coincided with that of $\mathrm{Wu}$ et al. [21], who reported that the alpha diversity of soil gradually increased along a temperature gradient from 10 to $30^{\circ} \mathrm{C}$, but sharply decreased at $40^{\circ} \mathrm{C}$.

Table 2. Alpha diversity of the bacterial community in sludge vermicomposting products at $15{ }^{\circ} \mathrm{C}, 20$ ${ }^{\circ} \mathrm{C}$, and $25^{\circ} \mathrm{C}$.

\begin{tabular}{cccc}
\hline Sample Name & Shannon & Simpson & Chao1 \\
\hline $15^{\circ} \mathrm{C}$ & 6.88 & 0.973 & 1373.25 \\
$20^{\circ} \mathrm{C}$ & 6.98 & 0.972 & 1508.01 \\
$25^{\circ} \mathrm{C}$ & 7.06 & 0.974 & 1651.31 \\
\hline
\end{tabular}

In contrast, the Simpson index showed the values for the three treatments were even higher than 0.97 , and no obvious difference was recorded between these treatments, suggesting that temperature did not affect microbial evenness. Further, the observed amount of bacteria (Figure $4 \mathrm{a}$ ) at $15{ }^{\circ} \mathrm{C}, 20^{\circ} \mathrm{C}$, $25^{\circ} \mathrm{C}$ was 1249,1358 , and 1501 , respectively. The amount of bacteria at $15^{\circ} \mathrm{C}$ was lower by $8.7 \%$ and $20.2 \%$ than at $20^{\circ} \mathrm{C}$ and $25^{\circ} \mathrm{C}$, respectively. In addition, the specific species at $15^{\circ} \mathrm{C}, 20^{\circ} \mathrm{C}$, and $25^{\circ} \mathrm{C}$ amounted to 164,256 , and 340 , respectively. These results suggest that high temperature conditions can strongly increase the number of bacterial species, forming a different bacterial community in the final vermicompost. 


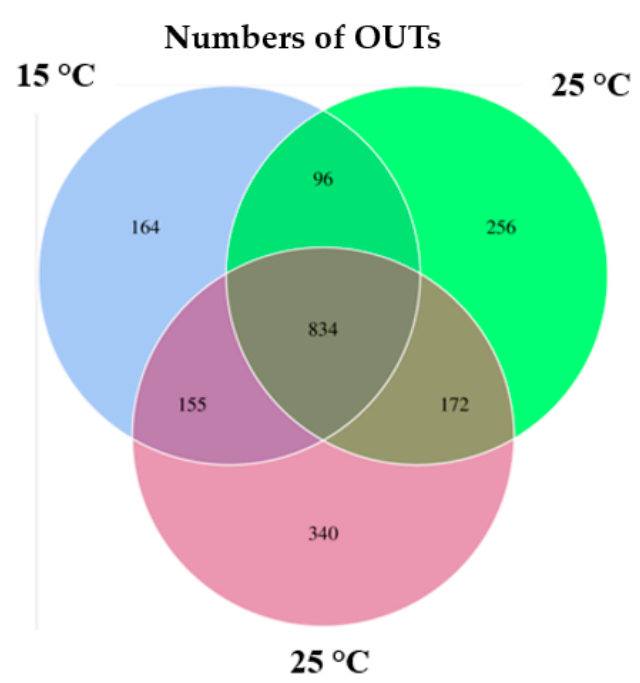

(a)

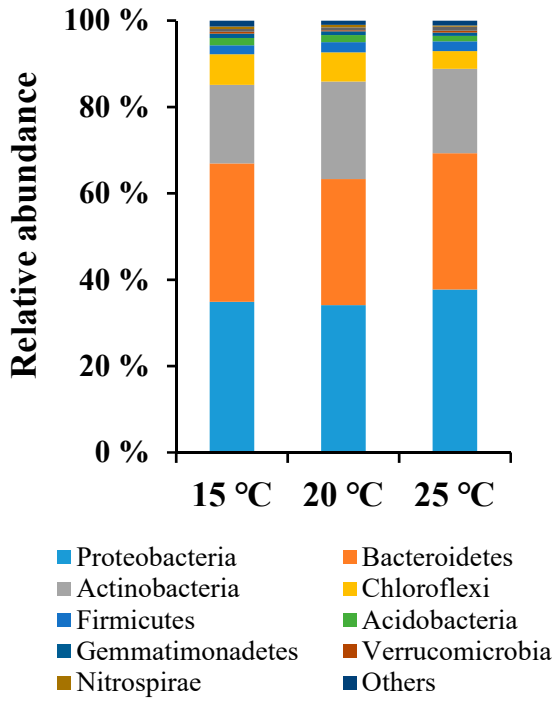

(b)

Figure 4. Bacterial components of operational taxonomic units (OTUs) number (a) and phylum communities $(\mathbf{b})$ at the different treatments.

As summarized in Figure $4 \mathrm{~b}$, the classified OTUs at the phylum level showed a shift in the bacterial community structure between the three temperatures. The $15^{\circ} \mathrm{C}$ treatment was dominated by the Proteobacteria (34.1\%), Bacteroidetes (32.1\%), and Actinobacteria (18.2\%). In comparison, Proteobacteria $(34.8 \%)$ also dominated at $20^{\circ} \mathrm{C}$, followed by Bacteroidetes (30.2\%) and Actinobacteria (19.2\%), as well as at $25{ }^{\circ} \mathrm{C}$ (Proteobacteria $37.7 \%$, Bacteroidetes $31.6 \%$, Actinobacteria $20.6 \%$ ). These observations were consistent with previous reports that the same group dominated in the sludge vermicompost $[6,27]$. In addition, Proteobacteria and Actinobacteria showed relative sensitivity to temperature, since their shares increased with temperature. The positive relationship between temperature and the shares of Proteobacteria and Actinobacteria was also observed previously [21].

Notably, Chloroflexi displayed an opposite trend to the increasing temperature in this study. As exhibited in Figure 5, the dominant genera of bacteria showed a dissimilar pattern with temperature change during vermicomposting of sludge (Figure 5). The $15{ }^{\circ} \mathrm{C}$ treatment was dominated by Terrimonas (3.9\%), Amphiplicatus (2.2\%), Tetrasphaera (1.1\%), and others genera, including Methanosaeta, Lautropia, Stenotrophobacter, and unidentified Gemmatimonadaceae. The Candidatus Microthrix (11.6\%) was the predominant taxon at $20{ }^{\circ} \mathrm{C}$, followed by Trichococcus $(5.3 \%)$ and Mycobacterium $(1.2 \%)$. Additionally, members of Dokdonella (10.7\%), unidentified Saprospiraceae (6.5\%), Rhodanobacter (2.1\%), and Thermomonas $(1.6 \%)$ were the dominants at $25^{\circ} \mathrm{C}$. Such results indicate that temperature can strongly influence bacterial community structuring in the final sludge vermicompost. These results were consistent with previous studies of soil [21], compost [19], and anaerobic systems [17]. Higher temperature may enhance mortality and reduce the stochastic processes of birth and colonization of microorganisms [22], thus promoting diversification in ecological niches. Wu et al. [21] demonstrated that every $1{ }^{\circ} \mathrm{C}$ elevation in soil temperature could lead to a change of about $36.5 \%$ in the community structure of bacteria per year.

In addition, the predominant bacterial taxon is strongly associated with the vermicomposting function. For instance, the presence of Terrimonas, a member of the family Chitinophagaceae, could indicated high degradation, since members of this genus have been previously shown to actively degrade organic compounds and cellulose, which are also often isolated from the activated sludge [13,33]. Candidatus Microthrix, on the other hand, are ubiquitous lipid-accumulating filamentous bacteria that not only cause bulking and foaming, but can also assimilate diverse carbon substrates while being adaptable to a wide range of environmental conditions [34]. Dokdonella, which are strictly 
aerobic and urease-negative rods with an optimum growth temperature of $40{ }^{\circ} \mathrm{C}$, are also usually found in compost [35] and vermicompost [13]. Hence, in this study, the striking difference in the composition of bacterial genera in contrasting environments may directly affect stabilization of the sludge. Although $30^{\circ} \mathrm{C}$ may be an optimal temperature for bacterial growth and community succession, E. fetida was not able to survive in the warmer condition, affecting the vermicomposting process. Thus, it seems that $25^{\circ} \mathrm{C}$ could be the best vermicomposting condition, as it exhibited the highest activities of both earthworms and microorganisms, making it an optimal temperature for vermicomposting of dewatered sludge. On the other hand, since the highest temperature is only $25^{\circ} \mathrm{C}$, the sanitization for some biological pollutants, such as pathogens, antibiotic resistance genes, and viruses, is not complete in sludge vermicompost, because they are generally inactivated by processes involving increase in temperature [36]. Similarly, the heavy metals may not be effectively removed at this temperature. Therefore, the final environmental risk of sludge vermicompost should be assessed before it is used as a sludge fertilizer. Furthermore, the effects of temperature on reduction in toxicants in sludge during vermicomposting require further research.

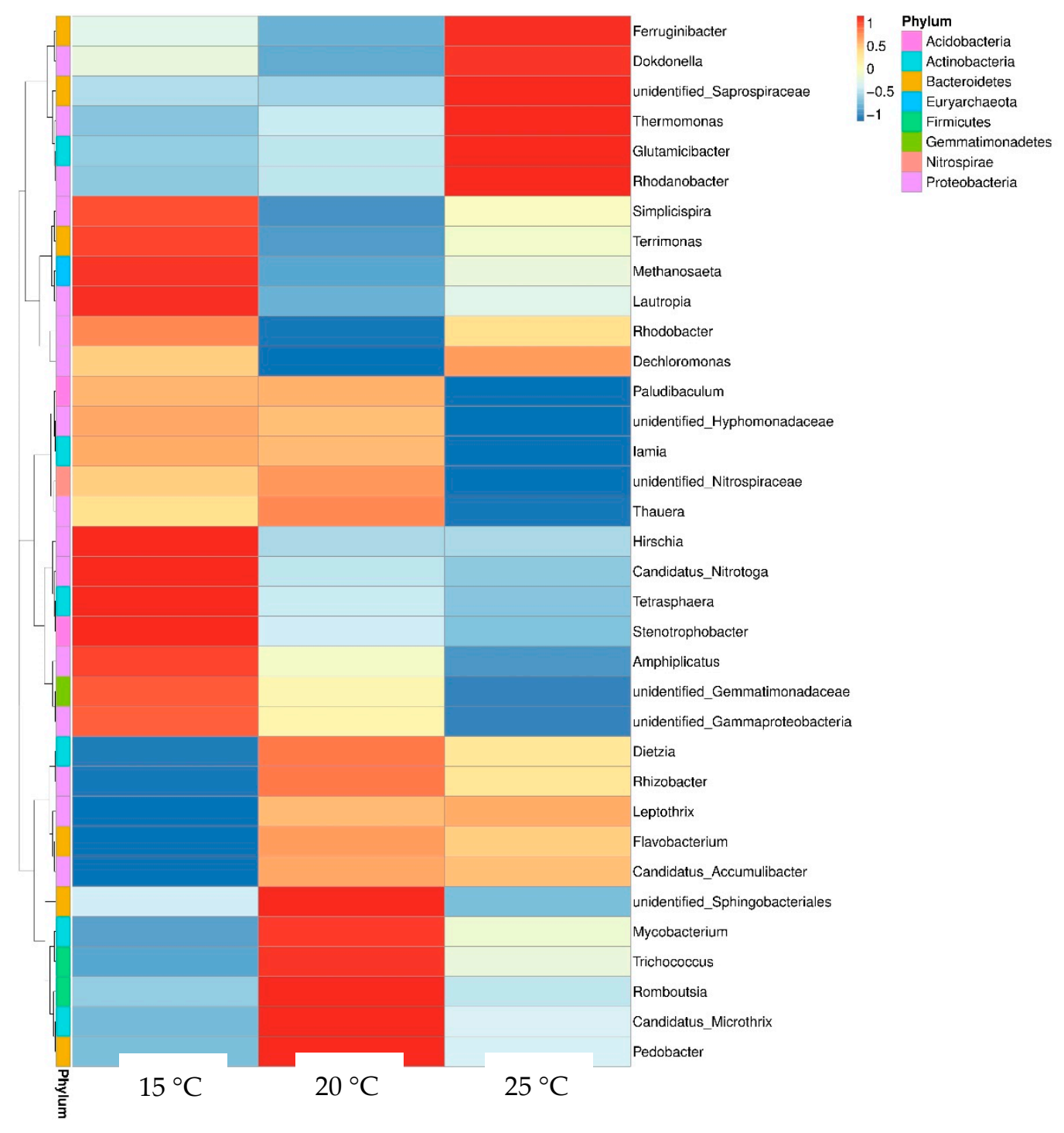

Figure 5. Heat map diagram of dominant bacteria for different sludge treatments at the genus level. 


\section{Conclusions}

The results obtained from this study indicate that temperature significantly affected decomposition and mineralization of sludge during vermicomposting, with the fastest stabilization process occurring at $25^{\circ} \mathrm{C}$. Higher temperature enhanced both microbial activity and earthworms' growth in the first 30 days, which could have rapidly stabilized the sludge. In addition, the alpha diversity of the bacterial community was strongly stimulated by a higher temperature, showing a distinct dominant genus in the final vermicompost. This study suggests that $25^{\circ} \mathrm{C}$ is the optimal temperature for vermicomposting of dewatered sludge with E. fetida. However, the environmental risk of heavy metals and pathogens in sludge vermicompost should be assessed before it is used as a sludge fertilizer.

Author Contributions: Conceptualization, H.Z. and K.H.; methodology, H.Z. and J.L.; software, J.L. and Y.Z.; validation, J.L. and Y.Z.; investigation, H.Z., J.L. and Y.Z.; resources, H.Z. and K.H.; data curation, J.L.; writing—original draft preparation, H.Z. and J.L.; writing—review and editing, K.H.; supervision, K.H.; funding acquisition, H.Z. and K.H. All authors have read and agreed to the published version of the manuscript.

Funding: We are grateful for the funds of the National Key Research and Development Project (2019YFD1100100) and the National Science Foundation of China (NSFC, 51868036) for this study.

Conflicts of Interest: The authors declared no potential conflicts of interest with respect to the research, authorship, and/or publication of this article.

\section{References}

1. Yang, G.; Zhang, G.M.; Wang, H.C. Current state of sludge production; management; treatment and disposal in China. Water Res. 2015, 78, 60-73. [CrossRef]

2. Zhang, Q.H.; Yang, W.N.; Ngo, H.H.; Guo, W.S.; Jin, P.K.; Dzakpasu, M.; Yang, S.J.; Wang, Q.; Wang, X.C.; Ao, D. Current status of urban wastewater treatment plants in China. J. Clean. Prod. 2016, 92, 11-22. [CrossRef] [PubMed]

3. Huang, Q.J.; Shen, Y.W.; Wang, Y.H.; Xiao, J.M.; Yuan, H.P.; Lou, Z.Y.; Zhu, N.W. Synergy between denitrification and calcium bridging improves dewaterability of waste activated sludge. J. Clean. Prod. 2020, 242, 118438. [CrossRef]

4. Singh, R.P.; Singh, P.; Araujo, A.S.; Ibrahim, M.H.; Sulaiman, O. Management of urban solid waste: Vermicomposting a sustainable option. Resour. Conserv. Recy. 2011, 55, 719-729. [CrossRef]

5. Lee, L.H.; Wu, T.Y.; Shak, K.P.Y.; Lim, S.L.; Ng, K.Y.; Nguyen, M.N.; Teoh, W.H. Sustainable approach to biotransform industrial sludge into organic fertilizer via vermicomposting: A mini-review. J. Chem. Technol. Biot. 2018, 93, 925-935. [CrossRef]

6. Huang, K.; Xia, H.; Wu, Y.; Chen, J.Y.; Cui, G.Y.; Li, F.S.; Chen, Y.Z.; Wu, N. Effects of earthworms on the fate of tetracycline and fluoroquinolone resistance genes of sewage sludge during vermicomposting. Bioresour. Technol. 2018, 259, 32-39. [CrossRef]

7. Yadav, A.; Garg, V.K. Biotransformation of bakery industry sludge into valuable product using vermicomposting. Bioresour. Technol. 2019, 274, 512-517. [CrossRef]

8. Domínguez, J.; Aira, M.; Gómez-Brandón, M. Vermicomposting: Earthworms enhance the work of microbes. In Microbes at Work; Springer: Berlin, Germany, 2010; pp. 93-114.

9. Marhan, S.; Auber, J.; Poll, C. Additive effects of earthworms; nitrogen-rich litter and elevated soil temperature on N2O emission and nitrate leaching from an arable soil. Appl. Soil Ecol. 2015, 86, 55-61. [CrossRef]

10. Hackenberger, D.K.; Palijan, G.; Lončarić, Ž.; Glavaš, O.J.; Hackenberger, B.K. Influence of soil temperature and moisture on biochemical biomarkers in earthworm and microbial activity after exposure to propiconazole and chlorantraniliprole. Ecotox. Environ. Safe. 2018, 148, 480-489. [CrossRef]

11. Edwards, C.A.; Lofty, J.R. Biology of Earthworm; Chapman \& Hall: London, UK, 1977.

12. Fu, X.Y.; Huang, K.; Cui, G.Y.; Chen, X.M.; Li, F.S.; Zhang, X.Y.; Li, F. Dynamics of bacterial and eukaryotic community associated with stability during vermicomposting of pelletized dewatered sludge. Int. Biodeter. Biodegr. 2015, 104, 452-459. [CrossRef]

13. Fu, X.Y.; Cui, G.Y.; Huang, K.; Chen, X.M.; Li, F.S.; Zhang, X.Y.; Li, F. Earthworms facilitate the stabilization of pelletized dewatered sludge through shaping microbial biomass and activity and community. Environ. Sci. Pollut. R. 2016, 25, 4522-4530. [CrossRef] [PubMed] 
14. Hait, S.; Tare, V. Optimizing vermistabilization of waste activated sludge using vermicompost as bulking material. Waste Manag. 2011, 31, 502-511. [CrossRef] [PubMed]

15. Hussain, N.; Abbasi, S. Efficacy of the vermicomposts of different organic wastes as "clean" fertilizers: State-of-the-art. Sustainability 2018, 10, 1205. [CrossRef]

16. Levén, L.; Nyberg, K.; Schnürer, A. Conversion of phenols during anaerobic digestion of organic solid waste-a review of important microorganisms and impact of temperature. J. Environ. Manag. 2012, 95, 99-103. [CrossRef] [PubMed]

17. Yuan, Y.; Liu, Y.; Li, B.K.; Wang, B.; Wang, S.Y.; Peng, Y.Z. Short-chain fatty acids production and microbial community in sludge alkaline fermentation: Long-term effect of temperature. Bioresour. Technol. 2016, 211, 685-690. [CrossRef] [PubMed]

18. Nikaeen, M.; Nafez, A.H.; Bina, B.; Nabavi, B.F.; Hassanzadeh, A. Respiration and enzymatic activities as indicators of stabilization of sewage sludge composting. Waste Manag. 2015, 39, 104-110. [CrossRef]

19. Koyama, M.; Nagao, N.; Syukri, F.; Rahim, A.A.; Kamarudin, M.S.; Toda, T.; Mitsuhashi, T.; Nakasaki, K. Effect of temperature on thermophilic composting of aquaculture sludge: NH3 recovery, nitrogen mass balance, and microbial community dynamics. Bioresour. Technol. 2018, 265, 207-213. [CrossRef]

20. Ma, X.J.; Xing, M.Y.; Wang, Y.; Xu, Z.; Yang, J. Microbial enzyme and biomass responses: Deciphering the effects of earthworms and seasonal variation on treating excess sludge. J. Environ. Manag. 2016, 170, $207-214$. [CrossRef]

21. Wu, J.F.; Xiong, J.B.; Hu, C.J.; Shi, Y.; Wang, K.; Zhang, D.M. Temperature sensitivity of soil bacterial community along contrasting warming gradient. Appl. Soil Ecol. 2015, 94, 40-48. [CrossRef]

22. Zhou, J.Z.; Deng, Y.; Zhang, P.; Xue, K.; Liang, Y.T.; Van Nostrand, J.D.; Yang, Y.F.; He, Z.L.; Wu, L.Y.; Stahl, D.A.; et al. Stochasticity, succession, and environmental perturbations in a fluidic ecosystem. Proc. Natl. Acad. Sci. USA 2014, 111, 836-845. [CrossRef]

23. Creamer, C.A.; De Menezes, A.B.; Krull, E.S.; Sanderman, J.; Newton-Walters, R.; Farrell, M. Microbial community structure mediates response of soil $\mathrm{C}$ decomposition to litter addition and warming. Soil Biol. Biochem. 2015, 80, 175-188. [CrossRef]

24. Domfnguez, J. 20 State-of-the-Art and New Perspectives on Vermicomposting Research. In Earthworm Ecology; CRC Press: Boca Raton, FL, USA, 2004; pp. 401-424.

25. Frederickson, J.; Howell, G. Large-scale vermicomposting: Emission of nitrous oxide and effects of temperature on earthworm populations. The 7th international symposium on earthworm ecology Cardiff Wales 2002. Pedobiologia 2003, 47, 724-730. [CrossRef]

26. Garg, V.K.; Gupta, R. Effect of temperature variations on vermicomposting of household solid waste and fecundity of Eisenia Fetida. Bioremediat. J. 2011, 15, 165-172. [CrossRef]

27. Xia, H.; Wu, Y.; Chen, X.M.; Huang, K.; Chen, J.Y. Effects of antibiotic residuals in dewatered sludge on the behavior of ammonia oxidizers during vermicomposting maturation process. Chemosphere 2019, 218, 810-817. [CrossRef]

28. Wu, Z.; Yin, B.; Song, X.; Qiu, J.; Cao, L.; Zhao, Q. Effects of salinity on earthworms and the product during vermicomposting of kitchen wastes. Int. J. Environ. Res. Public Health 2019, 16, 4737. [CrossRef]

29. Tourna, M.; Freitag, T.E.; Nicol, G.W.; Prosser, J.I. Growth, activity and temperature responses of ammonia-oxidizing archaea and bacteria in soil microcosms. Environ. Microbiol. 2008, 10, 1357-1364. [CrossRef]

30. Gubry-Rangin, C.; Novotnik, B.; Mandič-Mulec, I.; Nicol, G.W.; Prosser, J.I. Temperature responses of soil ammonia-oxidising archaea depend on pH. Soil Biol. Biochem. 2017, 106, 61-68. [CrossRef]

31. Feng, X.J.; Simpson, M.J. Temperature and substrate controls on microbial phospholipid fatty acid composition during incubation of grassland soils contrasting in organic matter quality. Soil Biol. Biochem. 2009, 41, 804-812. [CrossRef]

32. Bárcenas-Moreno, G.; Gómez-Brandón, M.; Rousk, J.; Bååth, E. Adaptation of soil microbial communities to temperature: Comparison of fungi and bacteria in a laboratory experiment. Global Change Biol. 2009, 15, 2950-2957. [CrossRef]

33. Jin, D.C.; Wang, P.; Bai, Z.H.; Jin, B.; Yu, Z.S.; Wang, X.X.; Zhuang, G.Q.; Zhang, H.X. Terrimonas pekingensis sp. nov., isolated from bulking sludge, and emended descriptions of the genus Terrimonas, Terrimonas ferruginea, Terrimonas lutea and Terrimonas aquatica. Int. J. Syst. Evol. Micr. 2013, 63, 1658-1664. [CrossRef] 
34. Sheik, A.R.; Muller, E.E.; Audinot, J.N.; Lebrun, L.A.; Grysan, P.; Guignard, C.; Wilmes, P. In situ phenotypic heterogeneity among single cells of the filamentous bacterium Candidatus Microthrix parvicella. ISME J. 2016, 10, 1274. [CrossRef] [PubMed]

35. Cunha, S.; Tiago, I.; Pires, A.L.; Da Costa, M.S.; Veríssimo, A. Dokdonella fugitiva sp. nov., a Gammaproteobacterium isolated from potting soil. Syst. Appl. Microbiol. 2006, 29, 191-196. [CrossRef] [PubMed]

36. Pampuro, N.; Dinuccio, E.; Balsari, P.; Cavallo, E. Evaluation of two composting strategies for making pig slurry solid fraction suitable for pelletizing. Atmo. Pollut. Res. 2016, 7, 288-293. [CrossRef]

(C) 2020 by the authors. Licensee MDPI, Basel, Switzerland. This article is an open access article distributed under the terms and conditions of the Creative Commons Attribution (CC BY) license (http://creativecommons.org/licenses/by/4.0/). 